\title{
Karakteristik Tingkat Kreativitas Siswa yang Memiliki Disposisi Matematis Tinggi dalam Menyelesaikan Soal Matematika
}

\author{
Dewi Patmalasari ${ }^{1}$, Dian Septi Nur Afifah ${ }^{2}$, Gaguk Resbiantoro ${ }^{3}$ \\ 1) Program Studi Pendidikan Matematika, STKIP PGRI Tulungagung. \\ ${ }^{2)}$ Program Studi Pendidikan Matematika, Universitas Negeri Surabaya. \\ ${ }^{3)}$ Pendidikan Sains, Universitas Sebelas Maret. \\ Email: dewip.aj@gmail.com
}

\begin{abstract}
Abstrak
Penelitian ini dilatarbelakangi oleh keberagaman ide siswa dalam menyelesaikan soal matematika. Tujuan penelitian ini adalah untuk mendeskripsikan tingkat kreativitas siswa yang memiliki disposisi matematis tinggi. Penelitian ini merupakan penelitian kualitatif, sehingga kehadiran peneliti sangat penting karena peneliti berperan sebagai instrumen utama. Dalam penelitian ini data dikumpulkan dengan metode angket, tes dan wawancara. Instrumen penunjang yang digunakan dalam penelitian ini adalah angket disposisi matematis, soal tes masalah matematika, dan pedoman wawancara. Analisis data yang digunakan mengacu terdiri dari tiga tahap yaitu mereduksi data, menyajikan data dan menarik kesimpulan. Dalam penelitian ini reduksi data dilakukan dengan mengelompokkan siswa kedalam tingkat disposisi matematis tinggi, sedang, dan rendah melalui angket disposisi matematis siswa. Selanjutnya data disajikan berupa deskripsi karakteristik tingkat kreativitas siswa yang memiliki disposisi matematis tinggi dalam menyelesaikan soal matematika. Selanjutnya dilakukan penarikan kesimpulan. Peneliti menggunakan triangulasi waktu untuk memeriksa keabsahan data. Hasil penelitian ini adalah siswa memiliki tingkat kreativitas 4 dan 3 .
\end{abstract}

Kata Kunci: tingkat kreativitas, disposisi matematis, menyelesaikan soal matematika

\section{Characteristic of student's level of creativity that have high mathematical disposition in mathematic problems solving}

\begin{abstract}
The research motivated by the student's idea of diversity in mathematic problems solving. The porpuse of this research is to describe student's level of creativity that have high mathematical disposition. This research is qualitative research, so the presence of researcher is very important because researcher acted as the main instrument. In this research, the techniques of data collection are questionnaire, test, and interview. While instruments that use in this study are student's mathematical disposition questionnaire, test of mathematic problems solving and guidelines for interviews. The analysis data used are data reduction, data displayed, and conclusions. In this research data reduction was done by grouping students into mathematical disposition rate high, medium, and low using student's mathematical disposition questionnaire. Then, data are presented in the form of a description of the characteristics of student's level of creativity that have high mathematical disposition in mathematic problems solving. Furthermore it carried out the withdrawal of the conclusion. Researcher use triangulation to check the validity of the data. The results of this research are student have creativity level 4 and 3 .
\end{abstract}

Keywords: level of creativity, mathematical disposition, mathematic problems solving. 


\section{PENDAHULUAN}

Perkembangan zaman yang begitu pesat menuntut sumber daya manusia yang berkualitas dan mampu berkompetensi dalam perkembangan ilmu pengetahuan dan teknologi. Oleh karena itu, untuk mengembangkan sumber daya manusia yang berkualitas dan mampu berkompetisi manusia dituntut untuk memiliki kemampuan berpikir kritis, kreatif, logis dan sistematis. Hal ini dipertegas oleh Siswono (2008) yang menyatakan bahwa perkembangan teknologi dan informasi saat ini tidak dapat dipungkiri merupakan buah dari kemampuan berpikir kreatif manusia.

Salah satu usaha untuk mendorong kemampuan berpikir kreatif adalah melalui pendidikan. Matematika adalah salah satu bidang yang dapat mendorong kemampuan berpikir kreatif. Hal ini diungkapkan dalam salah satu tujuan pembelajaran matematika, yang mana siswa diharapkan memiliki kemampuan logis, analitis, sistematis, kritis dan kreatif serta memiliki kemampuan bekerja sama (Depdiknas, 2006).

Berpikir kreatif tidak akan lepas dengan istilah kreativitas yang lebih umum dan banyak dikaji para ahli (Siswono, 2008). Berpikir kreatif dan kreativitas merupakan dua hal berbeda namun saling berkaitan. Berpikir kreatif merupakan suatu proses yang digunakan ketika seseorang memunculkan suatu ide baru, sedangkan kreativitas merupakan produk berpikir kreatif seseorang (Siswono \& Rosyidi, 2005).

Kreativitas merupakan suatu produk kemampuan berpikir untuk menghasilkan suatu cara atau sesuatu yang baru dalam memandang masalah. Untuk mengukur kreativitas digunakan beberapa aspek yaitu kefasihan, fleksibilitas dan kebaruan.

Kefasihan atau berpikir lancar artinya mampu menghasilkan banyak gagasan yang relevan dan memiliki arus pemikiran yang lancar (Munandar, 2012). Berpikir luwes atau fleksibel artinya mampu menghasilkan gagasangagasan yang seragam, mampu merubah arah pendekatan dan memiliki arah pemikiran yang berbeda-beda (Munandar, 2012). Kebaruan adalah atau berpikir orisinal berarti memberikan jawaban yang tidak lazim, lain dari yang lain, dan jawaban jarang diberikan kebanyakan orang (Munandar, 2012). Sedangkan Leikin \& Lev (2012) mendefinisikan ketiga aspek kreativitas sebagai berikut (1) fluency refers to the continuity of ideas, flow of associations, and use of basic and universal knowledge, (2) flexibility is associated with changing ideas, approaching a problem in various ways, and producing a variety of solutions, (3) novelty is characterized by a unique, new/fresh way of thinking and uniqueloriginal products of a mental or artistic activity.

Berdasarkan uraian para ahli, dapat disimpulkan bahwa terdapat tiga aspek untuk menilai kreativitas yaitu kefasihan dapat diukur dari banyaknya jawaban yang diberikan untuk sebuah masalah. Fleksibilitas dapat diukur dari banyaknya cara yang digunakan dalam menyelesaikan soal. Sedangkan kebaruan dapat diukur dari keunikan jawaban atau cara yang diberikan untuk suatu masalah. Indikator kreativitas yang digunakan dalam penelitian ini dapat dilihat pada Tabel 1.

Tabel 1. Indikator Kreativitas

\begin{tabular}{cl}
\hline \multicolumn{1}{c}{ Aspek } & \multicolumn{1}{c}{ Indikator } \\
\hline Kefasihan & $\begin{array}{l}\text { Siswa dapat memecahkan soal } \\
\text { dengan lebih dari satu jawaban } \\
\text { benar }\end{array}$ \\
Fleksibilitas & $\begin{array}{l}\text { Siswa dapat memecahkan soal } \\
\text { dengan beberapa cara berbeda }\end{array}$ \\
Kebaruan & $\begin{array}{l}\text { Siswa dapat menemukan cara atau } \\
\text { jawaban yang berbeda }\end{array}$ \\
\hline
\end{tabular}

National Council of Teachers of Mathematic (NCTM) menyatakan bahwa orang kreatif dalam matematika cenderung memiliki daya tarik dan apresiasi dalam me- 
ngerjakan matematika, dan cenderung untuk berpikir dan bertindak positif (Wardani, Sumarmo, \& Nishitani, 2011). Kecenderungan tersebut termasuk keinginan yang kuat untuk memilih strategi dalam memecahkan tugas-tugas matematika, percaya diri, motivasi dalam melihat solusi alternatif, rajin, rasa ingin tahu, dan kecenderungan untuk merefleksikan cara berpikir mereka (NCTM, 2000). NCTM menyebutnya sebagai mathematical disposition atau disposisi matematis. Pernyataan NCTM tersebut diperkuat oleh Wardani (2011) yang menyatakan bahwa disposisi matematika adalah prasyarat untuk mencapai kreativitas matematika.

Polking (Syaban, 2009), mengemukakan beberapa indikator disposisi matematis diantaranya adalah: sifat rasa percaya diri dan tekun dalam mengerjakan tugas matematik, memecahkan masalah, berkomunikasi matematis, dan berusaha mencari alternatif dalam memecahkan masalah, menunjukkan minat dan rasa ingin tahu, sifat ingin memonitor dan merefleksi cara mereka berfikir, berusaha mengaplikasikan matematika ke dalam situasi lain, menghargai peran matematika dalam kultur dan nilai, matematika sebagai alat dan bahasa.

Dalam penelitian ini, indikator disposisi matematis yang digunakan sesuai dengan indikator yang dikemukakan oleh Mahmudi (2010) yaitu: (1) percaya diri, (2) gigih atau ketekunan dalam mengerjakan tugas matematika, (3) berpikir terbuka atau fleksibel, (4) memiliki minat dan keingintahuan dalam belajar matematika, dan (5) monitor dan mengevaluasi.

Beberapa peneliti telah membahas mengenai disposisi matematis dan pemecahan masalah matematika. Namun masih sedikit yang mengulas tentang kreativitas dan disposisi matematis. Dalam penelitian Wardani (2011) telah membahas mengenai kreativitas matematika dan disposisi matematis, namun belum mengupas secara detail bagaimana karakteristik tingkat kreativitas siswa yang memiliki disposisi matematis tinggi dalam menyelesaikan soal matematika.

\section{METODE}

Penelitian ini dilaksanakan pada tanggal 13 Febuari sampai 28 April 2017 di SMP Negeri 3 Ngunut yang terletak di desa Ngunut, tepatnya di jalan Adil No. 52. Populasi dalam penelitian ini adalah kelas VIII SMP Negeri 3 Ngunut semester genap tahun pelajaran 2016/2017. Tujuan penelitian ini adalah memeroleh informasi mengenai tingkat kreativitas siswa yang memiliki disposisi matematis tinggi. Dalam penelitian ini, rancangan penelitian menggunakan pendekatan kualitatif, karena penelitian ini berusaha mengungkapkan gejala secara menyeluruh dengan mengumpulkan data dari latar alami dan memanfaatkan peneliti sebagai instrumen utama. Fokus penelitian ini adalah ingin mengetahui gambaran tentang tingkat kreativitas siswa yang memiliki disposisi matematis tinggi dalam menyelesaikan soal matematika. Gambaran tersebut diungkapkan dengan mendiskripsikan tingkat kreativitas siswa dalam menyelesaikan soal matematika pada materi lingkaran, dengan demikian penelitian ini termasuk jenis penelitian deskriptif.

Kehadiran peneliti dalam penelitian kualitatif sangat diperlukan, karena peneliti bertindak sebagai instrumen utama, yaitu sebagai perencana tindakan, pengumpul data, penganalisa data, dan pelopor temuan penelitian. Namun dalam peneliti memerlukan instrumen pendukung untuk membantu mengumpulkan data. Dalam penelitian ini kehadiran peneliti adalah sebagai pengamat partisipatif, yaitu pengamat berada di dalam kegiatan yang dilakukan kelompok tertentu, 
ia menciptakan peranan-peranan sendiri tanpa ikut dalam kepentingan kegiatan kelompok yang diamati (Sukmadinata, 2009). Dengan demikian peniliti tidak memberi pengaruh terhadap ativitas sumber data atau subjek penelitian.

Sumber data dalam penelitian adalah subjek dari mana data dapat diperoleh (Arikunto, 2010). Peneliti mengambil sampel dengan menggunakan teknik purposive sampling. Purposive sampling adalah pengambilan sampel dengan pertimbangan tertentu (Sugiyono, 2015). Peneliti melakukan observasi dan wawancara dengan guru mata pelajara matematika terlebih dahulu sebelum menentukan kelas yang akan menjadi subjek penelitian. Pemilihan kelas yang akan menjadi subjek penelitian memperhatikan kemampuan siswa mampu mengkomunikasikan pemikirannya secara lisan maupun tertulis. Sehingga dipilih satu kelas yaitu kelas VIII E sebagai subjek penelitian. Setelah kelas yang menjadi subjek penelitian ditentukan, peneliti memberikan angket disposisi matematis kepada siswa. Dalam tahap ini siswa dikelompokkan dalam tingkat disposisi matematis tinggi, sedang dan rendah. Dari hasil angket tersebut dipilih subjek dengan inisial DR untuk dianalisis. Subjek DR merupakan siswa yang memiliki disposisi matematis tinggi.

Teknik pengumpulan data merupakan langkah yang paling strategis dalam penelitian, karena tujuan utama dari penelitian adalah mendapatkan data (Sugiyono, 2015). Tanpa mengetahui teknik pengumpulan data, maka peneliti tidak akan mendapatkan data yang memenuhi standar data yang ditetapkan. Dalam penelitian ini teknik pengumpulan data yang digunakan adalah metode angket, tes dan wawancara. Pada teknik pengumpulan data dengan metode angket, digunakan instrumen peneli- tian berupa angket disposisi matematis siswa yang diadaptasi dari angket disposisi matematis siswa yang dikembangkan oleh Ali Mahmudi. Angket tersebut digunakan untuk mengategorikan siswa kedalam tingkat disposisi matematis tinggi, sedang dan rendah. Sedangkan instrumen tes yang digunakan dalam penelitian ini adalah soal tes masalah matematika pada materi lingkaran yang terdiri dari dua soal uraian. Dan instrumen yang digunakan pada teknik wawancara adalah pedoman wawancara.

Setelah data terkumpul dari hasil pengumpulan data, perlu segera dilakukan analisis data oleh peneliti. Analisis data yang digunakan peneliti dalam mengolah data penelitian ini mengacu pada model Miles dan Huberman (dalam Sugiyono, 2015) yang terdiri dari tiga tahap yaitu mereduksi data, menyajikan data dan menarik kesimpulan. Dalam penelitian ini reduksi data dilakukan dengan mengelompokkan siswa kedalam tingkat disposisi matematis tinggi, sedang, dan rendah melalui angket disposisi matematis siswa. Selanjutnya, peneliti berdiskusi dengan guru mata pelajaran matematika untuk memilih siswa yang akan menjadi subjek penelitian. Kemudian data yang diperoleh dari subjek penelitian menjadi fokus utama peneliti untuk dianalisis. Setelah data tereduksi, maka langkah selanjutnya adalah menyajikan data. Dalam penelitian ini, penyajian data berupa deskripsi karakteristik tingkat kreativitas siswa yang memiliki disposisi matematis tinggi dalam menyelesaikan soal matematika. Selanjutnya dilakukan penarikan kesimpulan sesuai dengan analisis data yang telah dilakukan.

Untuk menunjukkan bahwa temuan data yang diperoleh dari subjek penelitian adalah benar, maka dilakukan triangulasi. Triangulasi yang digunakan dalam penelitian ini adalah triangulasi waktu. Dalam peneli- 
tian ini, peneliti memberikan tes matematika dan melakukan wawancara terhadap subjek penelitian pada hari yang telah ditetapkan. Kemudian setelah beberapa hari, peneliti memberikan tes matematika dengan soal yang hampir sama dengan soal sebelumnya kepada subjek penelitian untuk selanjutnya dilakukan wawancara kembali.

\section{HASIL DAN PEMBAHASAN}

Pemilihan subjek penelitian dilakukan menggunakan hasil angket disposisi matematis siswa. Angket disposisi matematis diberikan kepada seluruh siswa kelas VIII E SMP Negeri 3 Ngunut yang terdiri dari 29 siswa. Hasil analisis instrumen angket disposisi matematis dapat dilihat pada Tabel 2.

Tabel 2. Hasil Angket Disposisi Matematis

\begin{tabular}{ccc}
\hline No. & Disposisi Matematis & Jumlah Siswa \\
\hline 1. & Tinggi & 5 \\
2. & Sedang & 19 \\
3. & Rendah & 5 \\
\hline
\end{tabular}

Dari hasil angket tersebut dipilih 1 subjek dengan disposisi matematis tinggi untuk dilakukan analisis. Subjek yang dipilih adalah siswa dengan inisial DR. Siswa tersebut memiliki skor angket tertinggi.

Satu pekan setelah pengisian angket dis-posisi matematis, siswa diberikan soal tes matematika. Soal tes tersebut telah divalidasi oleh dosen dan guru pengajar matematika di SMP Negeri 3 Ngunut. Sehingga dapat digunakan untuk mengukur tingkat kreativitas siswa dalam menyelesaikan soal matematika pada materi lingkaran.

Soal yang diberikan kepada subjek yaitu soal cerita pada materi lingkaran. Soal yang diberikan merupakan soal terbuka, sehingga memacu siswa untuk memikirkan berbagai jawaban dan cara penyelesaian. Dalam penelitian ini subjek mendapatkan soal sebanyak 2 nomor soal.

Pada soal nomor 1, DR dapat menyelesaikan soal dengan benar seperti Gambar 1 berikut:

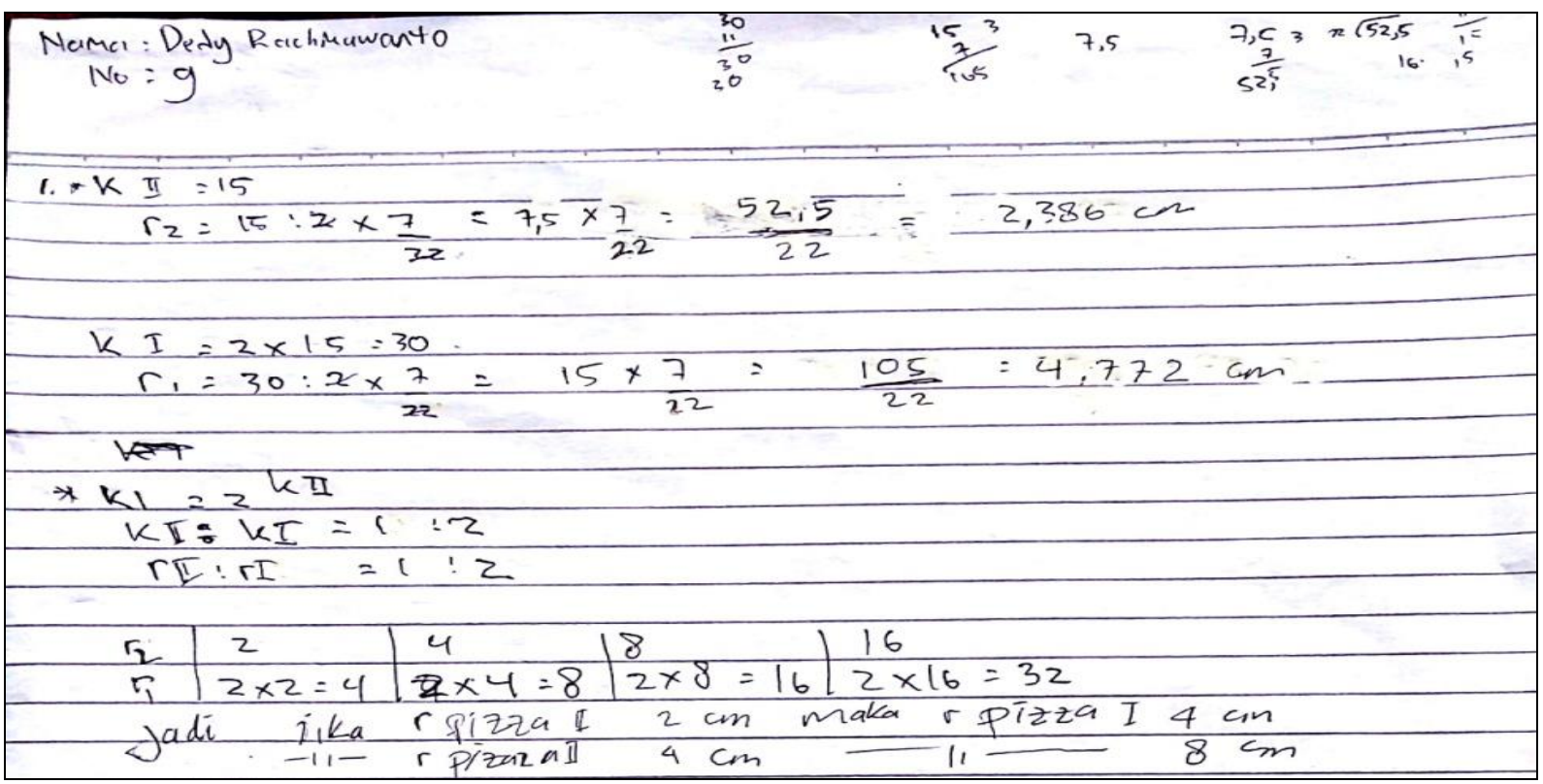

\section{Gambar 1. Hasil Tes Tulis DR untuk Soal Nomor 1}

Berdasarkan Gambar 1, DR menjawab menyelesaikan soal. Cara yang pertama, DR soal nomor satu dengan 5 jawaban benar. menentukan keliling pizza II terlebih dahulu Selain itu DR menggunakan 2 cara dalam kemudian mencari jari-jarinya lalu menentu- 
kan keliling pizza I dengan cara keliling pizza II dikalikan 2 selanjutnya mencari jari-jari pizza I. Cara kedua yang digunakan oleh DR ialah menggunakan skala. Berdasarkan hasil tertulis maka di-lakukan wawancara yang hasilnya sebagai berikut:

\section{$\mathrm{P} \quad$ : Apa ada cara lain?}

DR : Ada bu ....

$\mathrm{P}$ : Kenapa kamu menggunakan cara itu?

DR : Kalau diperhatikan dari jawaban pertama jari-jari pizza pertama sama dengan dua kali jari-jari kedua. jadi tinggal mengalikan saja untuk cari jawaban berikutnya....

Berdasarkan petikan wawancara dan hasil tertulis diatas, DR menjawab soal nomor 1 dengan 5 jawaban dengan benar, menggunakan 2 cara berbeda dalam menyelesaikan soal dan cara yang kedua merupakan cara yang yang lebih mudah untuk menyelesaikan soal yaitu dengan menggunakan skala.

DR memberikan lebih dari satu jawaban dengan benar. Hal ini menunjukkan bahwa DR fasih dalam menyelesaikan soal.
Dalam menyelesaikan soal, DR menggunakan cara yang telah dipelajari sebelumnya yaitu menggunakan rumus keliling lingkaran. Setelah menemukan jawaban dengan cara pertama, DR menemukan cara lain yang lebih mudah untuk menyelesaikan soal. DR memerhatikan jawaban pertama dan berhasil menemukan skala perbandingan jari-jari kedua pizza. DR telah menunjukkan aspek fleksibilitas dalam menyelesaikan soal dengan menggunakan dua cara berbeda untuk menyelesaikan soal. Aspek kebaruan juga muncul karena DR menemukan cara yang lebih mudah dengan mengaitkan matari lain yang telah dipelajari untuk menyelesaikan soal tersebut. Dengan demikian dapat disimpulkan bahwa DR memiliki tingkat kreativitas 4 dalam menyelesaikan soal nomor 1 .

Sedangkan pada soal nomor 2, DR menyelesaikan soal dengan benar seperti Gambar 1 berikut:

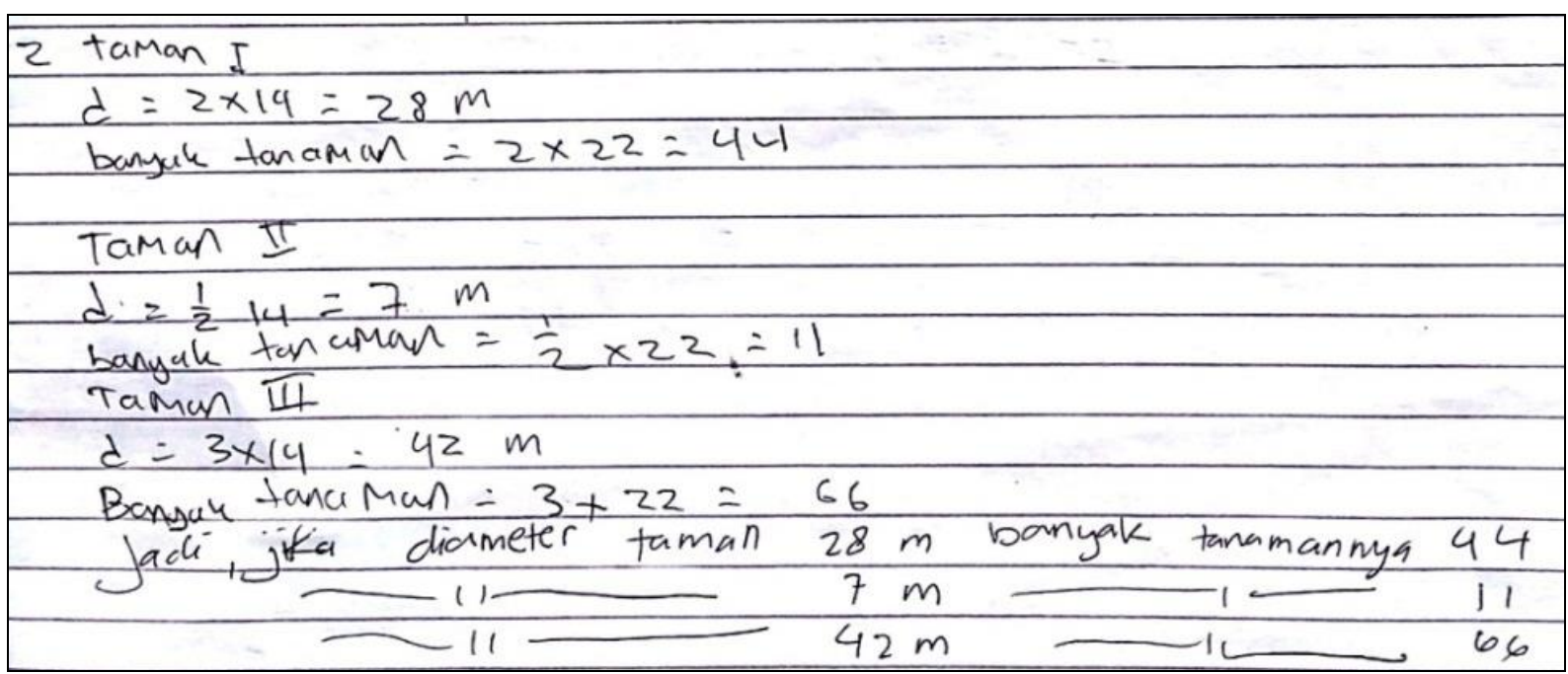

Gambar 2. Hasil Tes Tulis DR untuk Soal Nomor 2

DR hanya membuat satu cara untuk digunakan DR adalah cara yang baru yaitu menyelesaikan soal nomor dua. Cara yang menggunakan skala. Dengan cara memper- 
besar atau memperkecil ukuran taman yang lama, DR memberikan 3 jawaban dengan benar. Berdasarkan hasil tertulis maka dilakukan wawancara yang hasilnya sebagai berikut:

\section{P : Bagaimana kamu mengerjakan soal nomor dua?}

DR : Kan di nomor satu sudah ketemu perbandingannya jari-jari apabila diperbesar, jadi saya pakai cara itu. Lebih mudah.

$\mathrm{P} \quad$ : Kalau untuk mencari banyak tanamannya bagaimana?

DR : Ya tinggal diperbanyak berapa kali gitu bu.

DR : Kalau diameternya diperbesar 2 kali, tanamannya diperbanyak dua kali.

Berdasarkan petikan wawancara dan hasil tes tulis diatas, DR menjawab soal nomor 2 dengan 3 jawaban benar. Akan tetapi DR hanya menggunakan satu cara dalam menyelesaikan soal nomor dua dan cara yang digunakan merupakan cara yang baru. DR memanfaatkan skala untuk menyelesaikan soal nomor dua. Seperti yang telah ditemukan pada soal nomor satu. DR memahami bahwa apabila jari-jari atau diameter lingkaran diperbesar 2 kali maka keliling lingkaran tersebut juga akan diperbesar 2 kali. Sehingga banyak tanaman yang harus ada di keliling taman juga diperbanyak 2 kali.

DR memberikan lebih dari satu jawaban dengan benar. Hal ini menunjukkan bahwa DR fasih dalam menyelesaikan soal. Dalam menyelesaikan soal, DR menggunakan satu cara saja. DR mempelajari cara yang telah digunakan pada masalah nomor 1 untuk menyelesaikan soal nomor 2, yaitu dengan menggunakan skala. Hal ini menunjukkan bahwa DR telah memenuhi aspek kebaruan. Karena DR menunjukkan kefasihan dan kebaruan dalam menyelesaikan soal, maka dapat disimpulkan bahwa DR memiliki tingkat kreativitas 3 dalam menyelesaikan soal nomor 2 .

Subjek memberikan beberapa jawaban untuk setiap masalah yang disajikan. Subjek cenderung menyelesaikan soal dengan beberapa cara. Subjek cenderung memperbaiki cara yang telah digunakan agar lebih mudah menemukan jawaban. DR mempelajari cara pertama yang telah digunakan untuk menemukan cara yang lebih singkat. Sehingga DR cenderung memiliki tingkat kreativitas yang tinggi yaitu tingkat 4 pada soal nomor 1 dan tingkat 3 pada soal nomor 2 .

Subjek DR mengerjakan kedua soal dengan benar. Pada masing-masing soal, subjek menunjukkan aspek kreativitas yang berbeda. Pada soal pertama subjek menunjukkan aspek kefasihan, fleksibilitas dan kebaruan. Sedangkan pada soal kedua subjek menunjukkan kefasihan dan kebaruan. Perbedaan aspek yang muncul pada masing-masing soal tersebut dapat dilihat pada Tabel 3.

Tabel 3. Hasil Tes Tulis DR

\begin{tabular}{|c|c|}
\hline Soal Nomor 1 & Soal Nomor 2 \\
\hline $\begin{array}{l}\text { DR memberikan } 5 \\
\text { jawaban benar } \\
\text { menggunakan } 2 \\
\text { cara yang berbeda } \\
\text { DR menggunakan } \\
\text { rumus keliling } \\
\text { lingkaran untuk } \\
\text { mencari jari-jari } \\
\text { pizza } \\
\text { Dengan } \\
\text { memperhatikan } \\
\text { jawaban yang } \\
\text { ditemukan dengan } \\
\text { cara pertama, DR } \\
\text { menemukan cara } \\
\text { yang lebih mudah } \\
\text { untuk memecahkan } \\
\text { masalah yaitu } \\
\text { dengan } \\
\text { menggunakan skala }\end{array}$ & $\begin{array}{ll}\text { DR memberikan } 3 \\
\text { jawaban benar } \\
\text { DR memecahkan } \\
\text { masalah dengan } \\
\text { cara memperbesar } \\
\text { atau memperkecil } \\
\text { diameter taman } \\
\text { sebelumnya } \\
\text { selanjutnya } \\
\text { menentukan banyak } \\
\text { tanaman yang } \\
\text { diperlukan } \\
\text { menyesuaikan } \\
\text { dengan berapa kali } \\
\text { ukuran taman } \\
\text { diperbesar atau } \\
\text { diperkecil }\end{array}$ \\
\hline
\end{tabular}


Dengan adanya perbedaan yang dapat dilihat pada Tabel 3 tersebut, maka dapat diketahui bahwa subjek DR memiliki tingkat kreativitas yang berbeda pada setiap soal. Yaitu tingkat 4 pada soal nomor 1 dan tingkat 3 pada soal nomor 2. Perbedaan ini muncul karena subjek telah memahami bahwa cara kedua yang digunakan pada soal pertama dapat pula digunakan pada soal nomor dua. Cara tersebut dianggap cara paling cepat untuk menemukan banyak jawaban.

Dari pembahasan tersebut, dapat diketahui bahwa subjek DR cenderung memiliki tingkat kreativitas yang tinggi. Hal ini sesuai dengan pendapat Wardani et al. (2011) yang menyatakan bahwa siswa dengan kreativitas matematika tinggi biasanya menunjukkan disposisi matematis yang tinggi.

Apabila dilihat dari cara penyelesaian soal, subjek DR selalu mencari cara penyelesaian yang lebih mudah dari pada cara yang dingunakan sebelumnya. Hal ini sesuai dengan pendapat Trisnowali (2015) yang menyatakan bahwa siswa dengan disposisi matematis tinggi apabila diberi masalah matematika dia memiliki lebih dari satu cara penyelesaian dan juga subjek sering menjawab soal dengan berbagai macam penyelesaian atau bervariasi dan jawaban itu cenderung singkat dan lebih efektif.

\section{DAFTAR PUSTAKA}

Arikunto, S. (2010). Prosedur Penelitian Suatu Pendekatan Praktik. Jakarta: Rineka Cipta.

Depdiknas. (2006). Panduan Penyusunan Kurikulum Tingkat Satuan Pendidikan. Jakarta: Badan Standar Nasional Pendidikan.

Leikin, R., \& Lev, M. (2012). Mathematical creativity in generally gifted and mathematically excelling adolescents: what makes the difference?. ZDM The

\section{SIMPULAN}

Dalam menyelesaikan soal, siswa menggunakan dua cara yang berbeda, berkaitan dengan aspek kreativitas, siswa telah memenuhi aspek fleksibilitas. Siswa dengan disposisi matematis tinggi menemukan cara menyelesaikan soal yang lebih singkat dengan mempelajari cara pertama yang telah digunakan maupun mengaitkan dengan materi lain yang telah dipelajari sebelumnya, yang jarang terpikirkan oleh siswa lain. Hal tersebut menunjukkan siswa telah memenuhi aspek kebaruan dalam memecahkan masalah. Siswa dengan disposisi matematis tinggi memberkan beberapa jawaban dari sebuah masalah yang disajikan, hal ini menunjukkan aspek kefasihan. Dengan demikian siswa dengan disposisi matematis tinggi memiliki tingkat kreativitas yang tinggi dalam memecahkan masalah.

Bagi peneliti lain, sebaiknya dalam menyusun instrumen soal memunculkan semua aspek kreativitas pada setiap soal, khususnya untuk aspek kebaruan perlu memilih soal yang dapat memacing siswa menemukan ide-ide yang berbeda untuk memecahkannya.

\section{International Journal on Mathematics} Education. Retrieved from http://ecat.education.gov.il/Attachment/ DownloadFile?downloadId $=7748$

Mahmudi, A. (2010). Tinjauan Asosiasi antara Kemampuan Pemecahan Masalah Matematis dan Disposisi Matematis. In Seminar Nasional Pendidikan Matematika Diselenggarakan oleh Himpunan Mahasiswa Jurusan Pendidikan Matematika FMIPA Universitas Negeri Yogyakarta. Yogyakarta. Retrieved from http:// 
staffnew.uny.ac.id

Munandar, U. (2012). Pengembangan Kreativitas Anak Berbakat. Jakarta: Rineka Cipta.

NCTM. (2000). Disposition Toward Mathematics. Retrieved from http:// connected.ase.edu/

Siswono, T. Y. E. (2008). Model Pembelajaran Matematika Berbasis Pengajuan dan Pemecahan Masalah untuk Meningkatkan Kemampuan Berpikir Kreatif. Surabaya: Unesa University Press.

Siswono, T. Y. E., \& Rosyidi, A. H. (2005). Menilai Kreativitas Siswa dalam Matematika. In Prosiding Seminar Nasional Matematika dan Pendidikan Matematika "Peranan Matematika dan terapannya dalam meningkatkan Mutu Sumber Daya Manusia Indonesia" di jurusan matematika FMIPA Unesa. Surabaya. Retrieved from https://tatagyes.files. wordpress.com

Sugiyono. (2015). Memahami Penelitian Kualitatif. Bandung: Alfabeta.
Sukmadinata, N. S. (2009). Landasan Psikologi Proses Pendidikan. Bandung: PT Remaja Rosdakarya.

Syaban, M. (2009). Menumbuhkembangkan Daya dan Disposisi Matematis Siswa Sekolah Menengah Atas Melalui Pembelajaran Investigasi. EDUCATIONIST. Retrieved from http://www.file.upi.edu/ Trisnowali, A. (2015). Profil Disposisi Matematis Siswa Pemenang Olimpiade pada Tingkat Provinsi Sulawesi Selatan. Journal of EST, 1(3), 47-57. Retrieved from http://download.portalgaruda.org/

Wardani, S., Sumarmo, U., \& Nishitani, I. (2011). Mathematical Creativity and Disposition: Experiment with Grade-10 Students using Silver Inquiry Approach. 群馬大学教育学部紀要 自然科学編, 59, 1-16. Retrieved from gair.media. gunma-u.ac.jp 